\title{
The rapidly changing world of food allergy in children Katherine Anagnostou ${ }^{1}$, Rosan Meyer ${ }^{2}$, Adam Fox ${ }^{1}$ and Neil Shah ${ }^{2,3 *}$
}

Addresses: ${ }^{1}$ Department of Paediatric Allergy, Guy's and St Thomas' Hospitals NHS Foundation Trust, Westminster Bridge Road, London, SE1 7EH, UK; ${ }^{2}$ Department of Paediatric Gastroenterology, Great Ormond Street Children's Hospital, London, WC1N 3JH, UK;

${ }^{3}$ KULeuven, Targid - Herestraat 49, O\&N1, Box 701 - 3000 Leuven, Belgium

*Corresponding author: Neil Shah (neil.shah@gosh.nhs.uk)

Fl000Prime Reports 2015, 7:35 (doi:10.12703/P7-35)

All F1000Prime Reports articles are distributed under the terms of the Creative Commons Attribution-Non Commercial License (http://creativecommons.org/licenses/by-nc/3.0/legalcode), which permits non-commercial use, distribution, and reproduction in any medium, provided the original work is properly cited.

The electronic version of this article is the complete one and can be found at: http://f1000.com/prime/reports/m/7/35

\begin{abstract}
Food allergy is a common problem in childhood. The term is used to include both immunoglobulin E (IgE)-mediated and non-lgE-mediated food allergies, which have a significant effect on the quality of life of patients and their families. In this report, we aim to discuss recent advances in the diagnosis, management, and treatment modalities of food allergy in children.
\end{abstract}

\section{Introduction}

Food allergy is defined as an adverse immune response that occurs reproducibly on exposure to a given food. This is different from food intolerance, which refers to a nonimmunological adverse reaction to food, such as lactose intolerance (an enzyme deficiency) [1,2]. Food allergy is common, affecting $6 \%$ to $8 \%$ of children, and can be both life-impacting and life-threatening. The prevalence of food allergy is highest in infants and toddlers; $2.5 \%$ of infants suffer from milk allergy, and up to $10 \%$ of 1 -year-olds suffer from allergies to food, including cow's milk, egg, nuts, soya, wheat, and fish/shellfish $[1,3,4]$. There has been a rise in incidence in food allergies and other atopic diseases over the last three decades, and various hypotheses have attempted to explain this, such as the hygiene hypothesis, the timing and route of introduction of foods into the diet, and heredity $[5,6]$.

According to the World Allergy Organization guidance, food allergy can be IgE-mediated or non-IgE-mediated [7]. IgE-mediated food allergy typically has a rapid onset, affecting the skin, respiratory tract, and in some cases the gastrointestinal tract, whereas non-IgE-mediated food allergy usually has a delayed onset and affects the gastrointestinal tract and the skin [8].

Both have a significant effect on the quality of life of sufferers and their carers. Anxiety stems from fear of accidental ingestion, and allergic children face various dietary and social restrictions and school issues $[9,10]$. Clinician and parental frustration in non-IgE gastrointestinal allergies lies in the difficulty in diagnosis, ineffective treatments, and lack of validated tests, leading to both under- and overdiagnosis. Allergies to certain foods, such as cow's milk, soya, egg, and wheat, are usually outgrown after a few years and a period of dietary exclusion. Fish, shellfish, peanut, and tree nut allergy, on the other hand, tend to be life-long and rarely resolve [11]. Non-IgE-mediated gastrointestinal allergies may predispose to atopic and functional bowel co-morbidities in later childhood $[12,13]$.

Management of food allergies is currently based on the strict avoidance of the offending food (elimination diet) and prompt treatment of adverse reactions, resulting from accidental exposure $[2,14]$. Recently, the approach to both IgE-mediated and non-IgE-mediated allergy diagnosis and management has evolved via the use of anticipatory testing (IgE), better testing methods (non-IgE), early introduction of potentially allergenic foods, induction of tolerance to known allergens, and improved knowledge of non-IgEmediated allergic disorders.

\section{IgE-mediated food allergy Anticipatory testing}

Children with allergy to one food are at risk of having more food allergies [15]. Therefore, the initial presentation 
with one food allergy in high-risk patients should prompt further assessment. Otherwise, further food allergies will be discovered only when the child unexpectedly reacts on exposure, with potentially severe consequences. On the other hand, the child may be unnecessarily restricted from consuming foods considered 'high-risk' (for example, nuts) simply because of fear of reaction.

Recent guidelines, such as the National Institute for Health and Care Excellence (NICE) guidelines for food allergy, recommend allergy testing not only to the allergen suspected of causing the index reaction but also known co-allergens [16,17]. For example, testing for peanut allergy in children with egg allergy (estimated rate of co-allergy in approximately $20 \%$ to $30 \%$ ) $[18,19]$.

The presence of eczema in infancy is an important risk factor for the development of IgE-mediated food allergy. Hill and colleagues [20-23] showed that increasing severity of eczema during infancy and earlier age of onset are both risk factors for development of allergy [24,25]. A recent study by Mailhol and colleagues [24] demonstrated that children who are less than 2 years old and who have early-onset or severe eczema are at higher risk of food allergy and may be candidates for food allergy evaluation.

\section{Early dietary introduction of allergenic foods}

Currently, there is not sufficient evidence to support that maternal avoidance of allergenic foods has any benefits in preventing the development of food allergy in infants $[26,27]$. For infants at increased risk of atopy, the advice to delay introduction of solid foods until 6 months of age and of major food allergens until after 3 years of age has also been challenged [26]. Several studies have suggested that early introduction of an allergic food may actually play an important role in tolerance induction [28].

Katz and colleagues [29] have undertaken a prospective study investigating risk factors for cow's milk allergy. They have shown that infants with exposure to cow's milk protein in the first two weeks of life had a significantly lower incidence of cow's milk allergy compared with those infants who were introduced to cow's milk after the age of 4 to 6 months. It was concluded that early exposure to cow's milk protein may be protective against the development of IgE-mediated cow's milk allergy [29].

In a cross-sectional study, it has been suggested that early introduction of egg might have a protective effect against egg allergy. Infants introduced to cooked egg at 4 to 6 months had a lower risk of egg allergy than those introduced to cooked egg after that time [30]. In other studies, egg introduction before the age of 11 months was inversely associated with the development of asthma, allergic rhinitis, and atopic sensitization. In contrast, introduction of a limited number of foods at the age of 3 months was associated with an increase in atopic sensitization later in life [31,32].

Du Toit and colleagues [19] found a 10-fold higher prevalence of peanut allergy in the UK compared with Israel ( $1.85 \%$ versus $0.17 \%)$. Israeli infants start consuming peanut-containing foods during early weaning, whereas UK infants mostly avoid peanuts for the first three years of life. Early consumption of peanuts in infancy as well as consumption of frequent and high doses of peanut protein may be associated with a low prevalence of peanut allergy, possibly due to induction of oral tolerance [19].

Further data from ongoing interventional studies such as LEAP (Learning Early About Peanut allergy) are required to better understand whether early food introduction can actively help reduce the risk of food allergy [13]. Early introduction would also broaden the dietary repertoire of the infant and reduce the number of foods being avoided $[33,34]$.

\section{Active tolerance induction}

Recent studies investigating the natural history of cow's milk and egg allergy have shown that resolution rates are not as high as considered previously and that the majority of children develop tolerance in late childhood $[35,36]$. For children who are allergic to baked egg, for instance, it is less likely that tolerance will be developed by 2 years of age, according to recent research [37]. So far, the traditional approach to food allergy has been strict dietary avoidance. Recent evidence relating to new strategies to induce tolerance development has emerged $[2,38]$. Three areas have been of particular interest: the use of probiotics in infants with milk allergy, the role of baked egg and milk introduction in children with milk or egg allergies, and the role of desensitization to food.

There has been long-standing interest in the potential role of probiotics in modulating the allergic response in food allergy [39]. Maternal probiotic supplementation during pregnancy and breastfeeding has been shown to reduce the risk of eczema in high-risk infants [40]. Recently, Canani and colleagues [41,42] published several articles reporting accelerated cow's milk allergy tolerance acquisition in children receiving an extensively hydrolyzed casein formula with Lactobacillus GG (LGG) $(78.9 \%)$ versus the control without LGG (43.6\%).

Many parents had recognized that, despite a diagnosis of milk or egg allergy, their children could tolerate the 
allergen when it was extensively heated, such as baked in cakes. Studies revealed that $70 \%$ to $75 \%$ of milk and egg allergic children can tolerate the allergen when it was extensively heated $[43,44]$. Kim and colleagues [45] have shown that children who incorporated baked milk into their diet were 16 times more likely to become tolerant to all forms of milk compared with those who did not. Similarly, a study evaluating the role of baked egg in the development of tolerance to egg allergy has shown that subjects who were consuming baked egg products were 14 times more likely than the control group to develop tolerance to regular egg [46].

Another area that has made significant advances is food oral immunotherapy (OIT). Preliminary data are promising for OIT as an active treatment for food allergies. The administration of small but increasing doses of an allergenic food to children who are allergic to the food has been shown to increase their threshold of reactivity (desensitization), induce clinical tolerance, and enable them to eat varying amounts of the allergenic food without reactions $[47,48]$.

A recent Cochrane Review on the role of immunotherapy for milk allergy has highlighted the fact that, in children with cow's milk allergy, OIT increases the probability of achieving tolerance of cow's milk compared with elimination diet alone. However, its use in routine clinical practice is not recommended as yet [49].

OIT to foods appears to require regular consumption of the relevant allergen in order to maintain clinical tolerance. Discontinuation of OIT even for short periods of time (a few weeks) has so far resulted in loss of desensitization $[47,50]$. Families contemplating such therapy will need to weigh up the benefit of increased clinical tolerance against the risk of allergic reactions, compared with a strategy of complete avoidance. Phase III studies are required to further investigate long-term effects of this intervention.

\section{Non IgE-mediated food allergy Improved classification and recognition of symptoms}

The pathophysiology of non-IgE-mediated food allergy remains poorly described; however, there have been some advances in recognizing the overlap between IgEmediated and non-IgE-mediated allergy; in particular, the more recent National Institute of Allergy and Infectious Diseases (NIAID) guidelines now include a mixed IgE-mediated and non-IgE-mediated allergy, and eosinophilic esophagitis (EoE) and atopic eczema fall within this category [2]. Further to this mixed presentation, the association between atopic eczema and the presence of gastrointestinal symptoms, first highlighted by Latcham and colleagues [51], has recently been confirmed by Meyer and colleagues [52], and over 40\% of children with non-IgE-mediated protein-induced gastrointestinal allergies also presented with atopic eczema. Similar to the concomitant atopic co-morbidities in IgE-mediated allergies, data have also been published by the same research group on the presence of asthma and rhinitis, in addition to frequent upper respiratory tract infections in non-IgE-mediated allergies. This is over-represented in our population group and suggests that non-IgE-mediated allergies are a multi-system disorder whose exact mechanisms are yet to be elucidated [52].

Over the last decade, various non-IgE-mediated allergic conditions - in particular, EoE and food protein-induced enterocolitis syndrome (FPIES) - have received significant attention. Eosinophilic gastrointestinal disorders are classified according to the site of the inflammation and the depth and severity of the inflammation, which influences the presenting symptoms. The spectrum of pathologies (often with overlapping symptoms) includes EoE (the most common of these conditions), eosinophilic gastroenteritis, and eosinophilic gastroenterocolitis [53]. Although EoE is clearly associated with the atopic phenotype, the underlying mechanism is the subject of much investigation. Research has revealed that eosinophilic gastrointestinal disorders are primarily polygenic allergic disorders that involve mechanisms that fall between pure IgE-mediated and delayed T helper (TH) 2-type responses [54]. Eosinophils promote potent pro-inflammatory effects mediated by their release of cytotoxic granules and a variety of lipid mediators and cytokines. During TH2-associated gastrointestinal inflammatory conditions, increased levels of eosinophils occur in the lamina propria in an eotaxin 1-dependent manner. Furthermore, after mucosal allergen challenge, eosinophils under the regulation of interleukin-5 (IL-5) accumulate in the esophagus, an organ normally devoid of eosinophils at baseline. The local production of eotaxin-3, a potent eosinophil chemoattractant, appears to be pivotal. Inhalant allergens may also be implicated in older children and adolescents with EoE [54]. Although dietary exclusions are essential, they often are not sufficient to control symptoms, and pharmacological management is required.

FPIES is another non-IgE-mediated disorder that occurs in young infants, and the prevalence has been estimated at $0.36 \%$ by a retrospective study in the UK [55]. The most commonly reported FPIES food is cow's milk; however, it is also frequently reported with grains (that is, rice) and fish [56]. FPIES presents with profuse vomiting or diarrhea or both; additional symptoms may include 
pallor, lethargy, and neutrophilia, usually occurring within 2 to 4 hours after ingestion of the food [57]. This condition is frequently misdiagnosed; there may be long delays in reaching the correct diagnosis, and infants often have to undergo multiple unnecessary investigations [57]. Fortunately, the prognosis is good, and most children outgrow FPIES by 3 years of age $[57,58]$.

Several studies have now highlighted not only the gastrointestinal symptoms commonly seen in children with this type of allergy but also the high prevalence of feeding difficulties and the extra-intestinal manifestations, suggesting that this is a multi-system disorder. Recent diagnostic guidelines are in place to help health professionals distinguish these disorders from other medical conditions [59-61].

Data from 437 children with food protein-induced gastrointestinal allergies indicate that $30 \%$ to $40 \%$ of them have feeding difficulties [62]. In particular, the presence of vomiting, constipation, and abdominal discomfort has been associated with the development of feeding difficulties. The presence of feeding difficulties in children with suspected non-IgE-mediated food allergy has been included in the NICE UK guidance to aid diagnosis [61]. Non-IgE-mediated food allergy is also associated with extra-intestinal manifestations such as joint pain, fatigue, night sweats, and headaches, although much more work is needed to understand the underlying pathophysiological mechanisms. In addition, these children often suffer from frequent, prolonged respiratory infections and may have associated minor immune deficiencies $[52,62]$.

Food allergy may have a role to play in other gastrointestinal conditions. For example, persistent colic, gastroesophageal reflux unresponsive to pharmacotherapy, and persistent constipation may be attributed to allergic causes, such as non-IgE-mediated milk allergy. It may be useful to consider an appropriate trial of elimination diet for the suspected food allergen in order to assess symptomatic response. These conditions are rarely associated with IgE-mediated food allergy, and so skin prick tests and food-specific IgE are unlikely to be helpful.

\section{Long-term consequences: predisposition to functional bowel problems and the allergic march}

Functional gastrointestinal disorders (FGIDs) are the clinical product of an interaction between psychosocial factors and altered gut physiology via the brain-gut axis. In an effort to help clinicians obtain a better understanding and classification of these disorders and make the correct diagnosis for patients, the Rome III criteria were produced. The documents were the result of the work of 87 internationally recognized investigators representing 18 countries. It is suggested that better recognition of FGIDs may prevent long-term morbidity [63].

Based on the Rome III criteria for diagnosis, FGIDs are classified first by age range (neonate/toddler and child/ adolescent) and then by symptom pattern or area of symptom location. Each category site contains several disorders, each having relatively specific clinical features. So the functional bowel disorders include irritable bowel syndrome, functional bloating, functional constipation, and functional diarrhea, which anatomically is attributed to the small bowel, colon, and rectum [63].

Food allergy can be a predisposing factor for FGIDs in children. A case-control pediatric study by Saps and colleagues [12] included 52 children who were diagnosed with cow's milk allergy in the first year of life (cases) and 53 siblings without a history of cow's milk allergy (controls). Abdominal pain was significantly more common in cases $(30.8 \%)$ versus controls $(9.43 \%)$ (odds ratio 3.03, $P=0.01$ ), and the authors concluded that cow's milk allergy constitutes a risk factor for the development of functional gastrointestinal disorders in children.

The term "allergic march" refers to the progression of atopic diseases, which is characterized by a typical sequence of IgE antibody responses and clinical symptoms that appear early in life, persist over years or decades, and often remit spontaneously with age. In general, atopic dermatitis is the first clinical manifestation of the $\operatorname{IgE}$ response, and the highest incidence is during the first 3 months of life. This is followed by the emergence of food allergy in the first 3 years of life. Seasonal allergic rhinoconjunctivitis is generally not observed during the first 2 years of life, although a minority of children will develop specific IgE antibodies during this early period. Allergic rhinitis may be followed by seasonal allergic asthma as part of the atopic phenotype [64].

\section{Diagnostic methods}

The diagnosis of non-IgE-mediated food allergy is generally based on elimination diets, followed by reintroduction of the suspected foods, with the addition of intestinal biopsies, when needed. Recently, the lymphocyte stimulation test (LST) for $\kappa$-casein was proposed as an alternative diagnostic test for intestinal cow's milk allergy (ICMA) [65]. A study that evaluated the diagnostic value of LST in a large number of patients with ICMA in Japan included 96 infants who developed intestinal symptoms after ingestion of cow's milk formula and showed remission of symptoms after elimination of this food. Seventy-two subjects with normal cow's milk-IgE 
levels and a positive result in an oral food challenge test (OFCT) for cow's milk formula were diagnosed with ICMA. Ten infants with normal cow's milk-IgE levels and a negative OFCT result were diagnosed with non-specific intestinal symptoms (NISs). In the 72 patients with ICMA, $86.1 \%$ of patients tested positive in the LST for $\kappa$-casein. In contrast, only 2 of the 10 NIS infants tested positive. The incidence of a positive LST result was significantly higher in the ICMA group than in the NIS group $(P<0.0001)[65]$.

Recent guidelines on the diagnosis of EoE recommend that at least two to four biopsies be taken from both the proximal and distal esophagus to maximize diagnostic sensitivity [66]. In symptomatic children with positive histological findings for EoE, a trial of proton pump inhibitors is recommended for 8 weeks in order to diagnose responsive esophageal eosinophilia [66]. Studies have shown that up to $40 \%$ of children with esophageal eosinophilia have responded histologically to proton pump inhibitor therapy [67]. Recently, gene expression profiling has been used for the molecular diagnosis of EoE with the aim to develop a test that can differentiate EoE from controls and also EoE remission from active disease. However, a biopsy is still required for diagnostic confirmation [68].

\section{New treatment strategies}

In a similar way to IgE-mediated food allergy, it has been shown that most adults with EoE are able to tolerate baked milk [69]. This may also be applicable to children, although current published literature included adult subjects only. The destruction of conformational epitopes of cow's milk has been suggested as the underlying mechanism of baked milk tolerance in IgE-mediated cow's milk allergy [43]. Whether allergen-specific IgE is expressed and plays a role in EoE is unknown. The observation of clinical tolerance of baked milk in a subset of patients with EoE supports a role for an IgE-mediated mechanism [69]. The ability to add baked milk products back into the diet may improve compliance, quality of life, and nutrition. Commonly used allergen testing modalities (skin prick testing, patch testing, and specific IgE testing) are not helpful in predicting the outcome of baked milk ingestion [69].

Current treatment of EoE is based on inflammation control with steroids (oral or topical) or food antigen avoidance or both. However, such treatment options are not specific, reduce the quality of life of patients, and have significant side effects; therefore, there is a significant ongoing effort to design additional studies of specific immunotherapy. Anti-IL-5 treatment has been shown to significantly decrease eosinophil numbers in the esophageal biopsies in adults and children with EoE. However, very few patients reached normal levels, and the clinical response was not different from placebo. The use of anti-tumor necrosis factor-alpha and anti-IgE in small studies has shown no efficacy in treating EoE so far [70].

\section{Conclusions}

For many years, management of food allergy consisted of allergen avoidance and emergency treatment while waiting for allergies to be outgrown. However, a more active approach to management, drawing on the emerging evidence base, is helping to improve quality of life, prevent development of new allergies, and actively attempt to induce tolerance. For IgE-mediated food allergy, the future lies in prevention and early recovery by inducing tolerance or prevention by early introduction. For non-IgE-mediated food allergy, the path has already been defined by IgE-mediated disease with the need for better tests, early induction of tolerance, and better understanding of emerging conditions, such as EoE, which may in fact have been around for many years previously.

\section{Abbreviations}

EoE, eosinophilic esophagitis; FGID, functional gastrointestinal disorder; FPIES, food protein-induced enterocolitis syndrome; ICMA, intestinal cow's milk allergy; IgE, immunoglobulin E; IL, interleukin; LGG, Lactobacillus GG; LST, lymphocyte stimulation test; NICE, National Institute for Health and Care Excellence; NIS, non-specific intestinal symptom; OFCT, oral food challenge test; OIT, oral immunotherapy; $\mathrm{TH}$, T helper.

\section{Disclosures}

The authors declare that they have no disclosures.

\section{References}

I. Sampson HA: Update on food allergy. J Allergy Clin Immunol 2004, I I 3:805- | 9; quiz 820.

2. NIAID-Sponsored Expert Panel, Boyce JA, Assa'ad A, Burks AW, Jones SM, Sampson HA, Wood RA, Plaut M, Cooper SF, Fenton MJ, Arshad SH, Bahna SL, Beck LA, Byrd-Bredbenner C, Camargo CA Jr, Eichenfield L, Furuta GT, Hanifin JM, Jones C, Kraft M, Levy BD, Lieberman P, Luccioli S, McCall KM, Schneider LC, Simon RA, Simons FE, Teach SJ, Yawn BP, Schwaninger JM: Guidelines for the Diagnosis and Management of Food Allergy in the United States: Report of the NIAID-Sponsored Expert Panel Acknowledgments Primary Authors Office of Food Additive Safety. J Allergy Clin Immunol 2010, I26(6 Suppl):SI-58.

3. Sicherer SH, Sampson HA: Food allergy. J Allergy Clin Immunol 2010, I 25(2 Suppl 2):SI I6-25.

4. Osborne NJI, Koplin JJ, Martin PE, Gurrin LC, Lowe AJ, Matheson MC, Ponsonby AL, Wake M, Tang ML, Dharmage SC, Allen KJ, HealthNuts Investigators: Prevalence of challengeproven IgE-mediated food allergy using population-based sampling and predetermined challenge criteria in infants. J Allergy Clin Immunol 20I I, I 27:668-76.el-2. 
5. Strachan D: Family size, infection and atopy: the first decade of the 'hygiene hypothesis'. Thorax 2000, 55(SuppI I):2-10.

6. Lack G: Update on risk factors for food allergy. J Allergy Clin Immunol 2012, I29: I 187-97.

7. Johansson SGO, Bieber T, Dahl R, Friedmann PS, Lanier BQ, Lockey RF, Motala C, Ortega Martell JA, Platts-Mills TA, Ring J, Thien F, Van Cauwenberge P, Williams HC: Revised nomenclature for allergy for global use: Report of the Nomenclature Review Committee of the World Allergy Organization, October 2003. J Allergy Clin Immunol 2004, I I 3:832-6.

8. Lee LA, Burks AW: Food allergies: prevalence, molecular characterization, and treatment/prevention strategies. Annu Rev Nutr 2006, 26:539-65.

9. Avery NJ, King RM, Knight S, Hourihane JO: Assessment of quality of life in children with peanut allergy. Pediatr Allergy Immunol 2003, 14:378-82.

10. Klinnert MD, Silveira L, Harris R, Moore W, Atkins D, Fleischer DM, Menard-Katcher C, Aceves S, Spergel JM, Franciosi JP, Furuta G: Health-related quality of life over time in children with eosinophilic esophagitis and their families. J Pediatr Gastroenterol Nutr 2014, 59:308-16.

II. Burks AW, Tang M, Sicherer S, Muraro A, Eigenmann PA, Ebisawa M, et al.: ICON: food allergy. J Allergy Clin Immunol 2012, I29:906-20.

12. Saps $M$, Lu P, Bonilla S: Cow's-milk allergy is a risk factor for the development of FGIDs in children. J Pediatr Gastroenterol Nutr 201 I, 52:166-9.

\section{FIOOOPrime}

13. Domínguez-Ortega G, Borrelli O, Meyer R, Dziubak R, De Koker C, Godwin H, Fleming C, Thapar N, Elawad M, Kiparissi F, Fox AT, Shah N: Extraintestinal manifestations in children with gastrointestinal food allergy. J Pediatr Gastroenterol Nutr 2014, 59:210-4.

14. Meyer R, Schwartz C, Shah N: A review on the diagnosis and management of food-induced gastrointestinal allergies. Curr Allergy Clin Immunol 2012, 25: I0-7.

15. Sicherer SH, Sampson HA: Food allergy: Epidemiology, pathogenesis, diagnosis, and treatment. J Allergy Clin Immunol 2013, 133:291-307.e5.

16. CGII6 Food allergy in children and young people: Diagnosis and assessment of food allergy in children and young people in primary care and community settings. NICE guidelines. $201 \mathrm{I}$.

17. Sherwood E, Boyd A: Food allergy in children and young people. RCGP J Assoc 2012, 5:76-82.

18. Du Toit G, Roberts G, Sayre PH, Plaut M, Bahnson HT, Mitchell H, Radulovic S, Chan S, Fox A, Turcanu V, Lack G; Learning Early About Peanut Allergy (LEAP) Study Team: Identifying infants at high risk of peanut allergy: The Learning Early About Peanut Allergy (LEAP) screening study. J Allergy Clin Immunol 20|2, I3 I: |35-43.

19. Du Toit G, Katz Y, Sasieni P, Mesher D, Maleki S, Fisher HR, Fox AT, Turcanu V, Amir T, Zadik-Mnuhin G, Cohen A, Livne I, Lack G: Early consumption of peanuts in infancy is associated with a low prevalence of peanut allergy. J Allergy Clin Immunol 2008, 122:984-9|.

\section{FlOOOPrime}

20. Sporik R, Hill D, Hosking C: Specificity of allergen skin testing in predicting positive open food challenges to milk, egg and peanut in children. Clin Exp Allergy 2000, 30:1540-6.

\section{FlOOOPrime \\ RECOMMENDED}

21. Hill DJ, Heine RG, Hosking CS, Brown J, Thiele L, Allen KJ, Su J, Varigos G, Carlin JB: IgE Food Sensitization in Infants with Eczema Attending a Dermatology Department. J Pediatr 2007, |51:359-63.

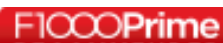

22. Hill DJ, Sporik R, Thorburn J, Hosking CS: The association of atopic dermatitis in infancy with immunoglobulin $E$ food sensitization. J Pediatr 2000, 137:475-9.

\section{FlOOOPrime \\ RECOMMENDED}

23. Hill DJ, Hosking CS, de Benedictis FM, Oranje AP, Diepgen TL, Bauchau V; EPAAC Study Group: Confirmation of the association between high levels of immunoglobulin $E$ food sensitization and eczema in infancy: an international study. Clin Exp Allergy 2008, 38: 16I-8.

\section{FlOOOPrime}

RECOMMENDED

24. Mailhol C, Giordano-Labadie F, Lauwers-Cances V, Ammoury A, Paul C, Rance F: Point prevalence and risk factors for food allergy in a cohort of 386 children with atopic dermatitis attending a multidisciplinary dermatology/paediatric allergy clinic. Eur J Dermatol 200 I, 24:63-9.

\section{FlOOOPrime
RECOMMENDED}

25. Martin P, Eckert J, Koplin J: Which infants with eczema are at risk of food allergy? Results from a population-based cohort. Clin Exp Allergy 2015, 45:255-64.

26. Greer FR, Sicherer SH, Burks AW: Effects of early nutritional interventions on the development of atopic disease in infants and children: the role of maternal dietary restriction, breastfeeding, timing of introduction of complementary foods, and hydrolyzed formulas. Pediatrics 2008, I21:183-91.

\section{FIOOOPrime \\ RECOMMENDED}

27. Fleischer DM, Spergel JM, Assa'ad AH, Pongracic JA: Primary prevention of allergic disease through nutritional interventions. J allergy Clin Immunol Pract 2013, 1:29-36.

28. Prescott SL, Smith P, Tang M, Palmer DJ, Sinn J, Huntley SJ, Cormack B, Heine RG, Gibson RA, Makrides M: The importance of early complementary feeding in the development of oral tolerance: concerns and controversies. Pediatr Allergy Immunol 2008, 19:375-80

29. Katz Y, Rajuan N, Goldberg MR, Eisenberg E, Heyman E, Cohen A, Leshno M: Early exposure to cow's milk protein is protective against IgE-mediated cow's milk protein allergy. J Allergy Clin Immunol 20I0, 126:77-82.el.

\section{FlOOOPrime
RECOMMENDED}

30. Koplin JJ, Osborne NJ, Wake M, Martin PE, Gurrin LC, Robinson MN, Tey D, Slaa M, Thiele L, Miles L, Anderson D, Tan T, Dang TD, Hill DJ, Lowe AJ, Matheson MC, Ponsonby AL, Tang ML, Dharmage SC, Allen $\mathrm{KJ}$ : Can early introduction of egg prevent egg allergy in infants? A population-based study. J Allergy Clin Immunol 2010, | 26:807-|3.

\section{FlOOOPrime \\ RECOMMENDED}

3I. Nwaru BI, Takkinen HM, Niemelä O, Kaila M, Erkkola M, Ahonen S, Tuomi H, Haapala AM, Kenward MG, Pekkanen J, Lahesmaa R, Kere J, Simell O, Veijola R, llonen J, Hyöty H, Knip M, Virtanen SM: Introduction of complementary foods in infancy and atopic sensitization at the age of 5 years: timing and food diversity in a Finnish birth cohort. Allergy 20I3, 68:507-16.

\section{FIOOOPrime}

32. Nwaru BI, Takkinen HM, Niemelä O, Kaila M, Erkkola M, Ahonen S, Haapala AM, Kenward MG, Pekkanen J, Lahesmaa R, Kere J, Simell O, Veijola R, llonen J, Hyöty H, Knip M, Virtanen SM: Timing of infant feeding in relation to childhood asthma and allergic diseases. J Allergy Clin Immunol 2013, 13 1:78-86.

33. Flammarion S, Santos C, Guimber D, Jouannic L, Thumerelle C, Gottrand F, Deschildre A: Diet and nutritional status of children with food allergies. Pediatr Allergy Immunol 20I I, 22:16I-5. 
34. Meyer R, De Koker C, Dziubak R, Venter C, Dominguez-Ortega G, Cutts R, Yerlett N, Skrapak AK, Fox AT, Shah N: Malnutrition in children with food allergies in the UK. J Hum Nutr Diet 2014, 27:227-35.

35. Skripak JM, Matsui EC, Mudd K, Wood RA: The natural history of IgE-mediated cow's milk allergy. J Allergy Clin Immunol 2007, 120:1172-7.

36. Savage JH, Matsui EC, Skripak JM, Wood RA: The natural history of egg allergy. J Allergy Clin Immunol 2007, I20:14I3-7.

37. Peters RL, Dharmage SC, Gurrin LC, Koplin JJ, Ponsonby A-L, Lowe AJ, Tang ML, Tey D, Robinson M, Hill D, Czech H, Thiele L, Osborne NJ, Allen KJ, HealthNuts study: The natural history and clinical predictors of egg allergy in the first $\mathbf{2}$ years of life: a prospective, population-based cohort study. J Allergy Clin Immunol 2014, 133:485-91.

38. Fiocchi A, Brozek J, Schünemann H, Bahna SL, von Berg A, Beyer K, Bozzola M, Bradsher J, Compalati E, Ebisawa M, Guzmán MA, Li H, Heine RG, Keith P, Lack G, Landi M, Martelli A, Rancé F, Sampson H, Stein A, Terracciano L, Vieths S; World Allergy Organization (WAO) Special Committee on Food Allergy: World Allergy Organization (WAO) Diagnosis and Rationale for Action against Cow's Milk Allergy (DRACMA) Guidelines. Pediatr Allergy Immunol 2010, 21 (Suppl 2I): I-I25.

39. Nermes $\mathrm{M}$, Salminen $\mathrm{S}$, Isolauri $\mathrm{E}$ : Is there a role for probiotics in the prevention or treatment of food allergy? Curr Allergy Asthma Rep 2013, 13:622-30.

40. Rautava S, Kainonen E, Salminen S, Isolauri E: Maternal probiotic supplementation during pregnancy and breast-feeding reduces the risk of eczema in the infant. J Allergy Clin Immunol 2012, I30:1355-60.

\section{FlOOOPrime}

\section{RECOMMENDED}

4l. Berni Canani R, Nocerino R, Terrin G, Frediani T, Lucarelli S, Cosenza L, Passariello A, Leone L, Granata V, Di Costanzo M, Pezzella V, Troncone R: Formula Selection for Management of Children with Cow's Milk Allergy Influences the Rate of Acquisition of Tolerance: A Prospective Multicenter Study. J Pediatr 2013, 163:77I-7.el.

\section{FIOOOPrime
RECOMMENDED}

42. Berni Canani R, Nocerino R, Terrin G, Coruzzo A, Cosenza L, Leone L, Troncone R: Effect of Lactobacillus GG on tolerance acquisition in infants with cow's milk allergy: a randomized trial. J Allergy Clin Immunol 2012, I 29:580-2 582.e I-5.

\section{FlOOOPrime}

43. Nowak-Wegrzyn A, Fiocchi A: Rare, medium, or well done? The effect of heating and food matrix on food protein allergenicity. Curr Opin Allergy Clin Immunol 2009, 9:234-7.

44. Lemon-Mulé H, Sampson HA, Sicherer SH, Shreffler WG, Noone S, Nowak-Wegrzyn A: Immunologic changes in children with egg allergy ingesting extensively heated egg. J Allergy Clin Immunol 2008, 122:977-983.el.

45. Kim JS, Nowak-Węgrzyn A, Sicherer SH, Noone S, Moshier EL, Sampson HA: Dietary baked milk accelerates the resolution of cow's milk allergy in children. J Allergy Clin Immunol 20II, | 28: |25-|3|.e2.

\section{FlOOOPrime}

46. Leonard SA, Sampson HA, Sicherer SH, Noone S, Moshier EL, Godbold J, Nowak-Węgrzyn A: Dietary baked egg accelerates resolution of egg allergy in children. J Allergy Clin Immunol 2012, I30:473-80.el.

\section{FlOOOPrime}

\section{RECOMMENDED}

47. Burks AW, Jones SM, Wood RA, Fleischer DM, Sicherer SH, Lindblad RW, Stablein D, Henning AK, Vickery BP, Liu AH,
Scurlock AM, Shreffler WG, Plaut M, Sampson HA; Consortium of Food Allergy Research (CoFAR): Oral immunotherapy for treatment of egg allergy in children. N Engl J Med 2012, 367:233-43.

\section{FlOOOPrime
RECOMMENDED}

48. Anagnostou K, Islam S, King Y, Foley L, Pasea L, Bond S, Palmer C, Deighton J, Ewan P, Clark A: Assessing the efficacy of oral immunotherapy for the desensitisation of peanut allergy in children (STOP II): a phase 2 randomised controlled trial. Lancet 2014, 383:1297-304.

\section{FlOOOPrime
RECOMMENDED}

49. Brożek JL, Terracciano L, Hsu J, Kreis J, Compalati E, Santesso N, Fiocchi A, Schünemann HJ: Oral immunotherapy for IgE-mediated cow's milk allergy: a systematic review and meta-analysis. Clin Exp Allergy 20I2, 42:363-74.

\section{FlOOOPrime
RECOMMENDED}

50. Vickery BP, Scurlock AM, Kulis M, Steele PH, Kamilaris J, Berglund JP, Burk C, Hiegel A, Carlisle S, Christie L, Perry TT, Pesek RD, Sheikh S, Virkud Y, Smith PB, Shamji MH, Durham SR, Jones SM, Burks AW: Sustained unresponsiveness to peanut in subjects who have completed peanut oral immunotherapy. J Allergy Clin Immunol 2014, I33:468-75.

FlOOOPrime

5I. Latcham F, Merino F, Lang A: A consistent pattern of minor immunodeficiency and subtle enteropathy in children with multiple food allergy. J Pediatr 2003, 143:39-47.

52. Meyer R, Fleming C, Dominguez-Ortega G, Lindley K, Michaelis L, Thapar N, Elawad M, Chakravarti V, Fox AT, Shah N: Manifestations of food protein induced gastrointestinal allergies presenting to a single tertiary paediatric gastroenterology unit. World Allergy Organ J 2013, 6:13.

53. Sampson HA, Aceves S, Bock SA, James J, Jones S, Lang D, Nadeau K, Nowak-Wegrzyn A, Oppenheimer J, Perry TT, Randolph C, Sicherer SH, Simon RA, Vickery BP, Wood R; Joint Task Force on Practice Parameters, Bernstein D, Blessing-Moore J, Khan D, Lang D, Nicklas R, Oppenheimer J, Portnoy J, Randolph C, Schuller D, Spector S, Tilles SA, Wallace D; Practice Parameter Workgroup, Sampson HA, et al.: Food allergy: A practice parameter update20 14. J Allergy Clin Immunol 2014, 134:1016-25.

54. Rothenberg ME: Eosinophilic gastrointestinal disorders (EGID). J Allergy Clin Immunol 2004, I I 3: I I-28;quiz 29.

55. Ludman S, Harmon M, Whiting D, du Toit G: Clinical presentation and referral characteristics of food protein-induced enterocolitis syndrome in the United Kingdom. Ann Allergy Asthma Immunol 20|4, I| 3:290-4.

56. Sopo SM, Giorgio V, Dello lacono I, Novembre E, Mori F, Onesimo R: A multicentre retrospective study of 66 Italian children with food protein-induced enterocolitis syndrome: different management for different phenotypes. Clin Exp Allergy 2012, 42: 1257-65.

57. Mehr S, Kakakios A, Frith K, Kemp AS: Food protein-induced enterocolitis syndrome: 16-year experience. Pediatrics 2009, 1 23:e459-64.

\section{FlOOOPrime}

RECOMMENDED

58. Nowak-Wegrzyn A, Muraro A: Food protein-induced enterocolitis syndrome. Curr Opin Allergy Clin Immunol 2009, 9:37I-7.

59. Dellon ES, Gonsalves N, Hirano I, Furuta GT, Liacouras CA, Katzka DA: ACG clinical guideline: Evidenced based approach to the diagnosis and management of esophageal eosinophilia 
and eosinophilic esophagitis (EoE). Am J Gastroenterol 2013, 108:679-92; quiz 693

\section{FlOOOPrime}

60. Koletzko S, Niggemann B, Arato A, Dias JA, Heuschkel R, Husby S, Mearin ML, Papadopoulou A, Ruemmele FM, Staiano A, Schäppi MG, Vandenplas Y; European Society of Pediatric Gastroenterology, Hepatology, and Nutrition: Diagnostic approach and management of cow's-milk protein allergy in infants and children: ESPGHAN GI Committee practical guidelines. J Pediatr Gastroenterol Nutr 2012, 55:221-9.

\section{FlOOOPRime}

61. Sackeyfio A, Senthinathan A, Kandaswamy P, Barry PW, Shaw B, Baker M: Diagnosis and assessment of food allergy in children and young people: summary of NICE guidance. BMJ 20II, 55: d747.

\section{FlOOOPrime \\ RECOMMENDED}

62. Meyer $\mathrm{R}$, Rommel $\mathrm{N}$, Van Oudenhove L, Fleming C, Dziubak $\mathrm{R}$, Shah $\mathrm{N}$ : Feeding difficulties in children with food proteininduced gastrointestinal allergies. J Gastroenterol Hepatol 2014, 29: I764-9.

63. Drossman $D$ : The functional gastrointestinal disorders and the Rome III process. Gastroenterology 2006, I30:1377-90.

\section{FlOOOPrime \\ RECOMMENDED}

64. Kulig M, Bergmann R, Klettke U: Natural course of sensitization to food and inhalant allergens during the first 6 years of life. J Allergy Clin Immunol 1999, I03: I I73-9.
65. Kimura M, Oh S: Usefulness of lymphocyte stimulation test for the diagnosis of intestinal cow's milk allergy in infants. Int Arch Allergy Immunol 20I I, 157:58-64.

\section{FloOPrime}

\section{RECOMMENDED}

66. Papadopoulou A, Koletzko S, Heuschkel R, Dias JA, Allen KJ, Murch SH, Chong S, Gottrand F, Husby S, Lionetti P, Mearin ML, Ruemmele FM, Schäppi MG, Staiano A, Wilschanski M, Vandenplas Y; ESPGHAN Eosinophilic Esophagitis Working Group and the Gastroenterology Committee: Management guidelines of eosinophilic esophagitis in childhood. I Pediatr Gastroenterol Nutr 2014, 58: $107-18$.

\section{FIOOOPrime}

67. James JM: Predictors of Response to Proton Pump Inhibitor Therapy Among Children With Significant Esophageal Eosinophilia. Pediatrics 2009, I24(SuppI 2):SI24-SI 25.

68. Wen T, Stucke EM, Grotjan TM, Kemme KA, Abonia JP, Putnam PE, Franciosi JP, Garza JM, Kaul A, King EC, Collins MH, Kushner JP, Rothenberg ME: Molecular diagnosis of eosinophilic esophagitis by gene expression profiling. Gastroenterology 2013, 145:1289-99. FIOOOPrime
RECOMMENDED

69. Leung J, Hundal NV, Katz AJ, Shreffler WG, Yuan Q, Butterworth CA, Hesterberg PE: Tolerance of baked milk in patients with cow's milk-mediated eosinophilic esophagitis. J Allergy Clin Immunol 2013, 132:1215-1216.el.

\section{FlOOOPrime} RECOMMENDED

70. Cianferoni A, Spergel J: Immunotherapeutic approaches for the treatment of eosinophilic esophagitis. Immunotherapy 2014, 6:32I-3I. 